\title{
KEBIJAKAN HUKUM PIDANA TERHADAP TINDAK PIDANA KESUSILAAN BERDASARKAN INTERNET (CYBER SEX)
}

\author{
Melanie Pita Lestari \\ Universitas Bhayangkara Jakarta Raya \\ melanie.pita@dsn.ubharajaya.ac.id
}

\begin{tabular}{|c|c|c|}
\hline Naskah diterima: & Revisi: & Naskah disetujui: \\
$12 / 5 / 2019$ & $29 / 05 / 2019$ & $29 / 05 / 2019$ \\
\hline
\end{tabular}

\begin{abstract}
Abstrak
Salah satu masalah cyber crime yang juga sangat meresahkan dan mendapat perhatian berbagai pihak adalah masalah cyber crime di bidang kesusilaan (cyber pornography) khususnya child pornography dan cyber sex. Penyalahgunaan internet di dunia maya kini belum ada peraturan perundang-undangan yang mengaturnya secara khusus, terlebih yang dikaitkan dengan perbuatan asusila atau seks. Padahal di dunia cyber masalah yang berhubungan dengan seks menimbulkan berbagai permasalahan dalam aspek hukum, moral dan agama. Artikel ini bertujuan menganalisis peraturan hukum pidana baik masa kini maupun masa yang akan datang dalam menanggulangi kejahatan di bidang cybersex. Hasil penelitian menunjukkan bahwa pengaturan hukum terkait cybersex yang merupakan bentuk baru perzinahan harus segera dikedepankan baik secara penal maupun non penal. Upaya rekonstruksi sebagai upaya penanggulangan tetap menjadi kebutuhan. Di samping itu, upaya non penal pun dapat ditempuh dengan beberapa pendakatan, seperti; teknologi, budaya, dan regulasi administrasi.
\end{abstract}

Kata Kunci: kesusilaan, hukum pidana, cyber sex.

\begin{abstract}
One of the problems of cyber crime which is also very troubling and gaining the attention of various parties is the problem of cyber crime in the field of morality (cyber pornography) especially child pornography and cyber sex. The misuse of the internet in cyberspace has not yet had legislation that regulates it specifically, especially those associated with immoral acts or sex. Even though in the cyber world, problems related to sex cause various problems in legal, moral and religious aspects. This article aims to analyze criminal law regulations both now and in the future in tackling crime in the field of cybersex. The results of the study show that the regulation of laws related to cybersex which is a new form of adultery must be put forward immediately both in terms of reason and non-reasoning. The reconstruction effort as a response effort remains a necessity. In addition, non-reasoning efforts can be pursued by several approaches, such as; technology, culture and administrative regulation.
\end{abstract}

Keywords: morality, criminal law, cyber sex 


\section{PENDAHULUAN}

\section{A. Latar Belakang Masalah}

Perkembangan ilmu pengetahuan dan teknologi ternyata telah membawa dampak dalam perkembangan hukum termasuk hukum pidana, khususnya tentang masalah perbuatan (tindak pidana). Padahal kehidupan dunia modern saat ini tidak dapat terlepas dan bahkan seringkali bergantung pada kemajuan teknologi maju/canggih, khususnya di bidang informasi dan elektronik melalui jaringan internasional (internet).

Penerapan teknologi internet telah menyentuh seluruh aspek kehidupan masyarakat. Hal ini telah menyebabkan perubahan cara berpikir dan bertindak masyarakat suatu bangsa. Tak terkecuali perubahan sikap masyarakat terhadap hukum yang berlaku. Penggunaan internet pun telah membentuk masyarakat dunia baru yang tidak dihalangi oleh batas-batas teritorial suatu negara yang dahulu ditetapkan sangat esensial yaitu dunia maya, dunia tanpa batas (borderless world)dengan realitas virtual (virtual reality.) $)^{1}$

Di satu sisi, kemajuan teknologi canggih membawa dampak positif di berbagai kehidupan, seperti adanya e-mail, e-commerce, e-learning, "EFTS" (elektronik funds transfer system, internet banking; cyber bank; online business, dan sebagainya, namun di sisi lain, juga membawa dampak negatif yang berpotensi membuat orang cenderung melakukan perbuatan yang bertentangan dengan norma-norma sosial yang berlaku, yaitu dengan munculnya berbagai jenis "hitech crime" dan "cyber crime", ${ }^{2}$ sehingga dinyatakan bahwa cyber crime is part of the seamy side of the information society (cyber crime merupakan bagian sisi paling buruk dari masyarakat informasi). ${ }^{3}$

Semakin berkembanganya cyber crime terlihat pula dari munculnya berbagai istilah seperti economic cyber crime, EFT (electronic funds transfer) crime, Cybank Crime, Internet Banking Crime, On-line Business Crime, Cyber/elektronic Money Laundering, Hitech WCC (white collar crime, Internet Fraud (antara lain Bank Fraud, Credit Card Fraud, Online Fraud), cyber terrorism, cyber stalking, cyber sex, cyber pornograhpy, cyber defamation, cyber criminals, dan sebagainya.

\footnotetext{
1 Onno W Purbo dalam Agus Raharjo, Cyber Crime, Pemahaman dan Upaya Pencegahan Kejahatan Berteknologi, Bandung: PT Citra Aditya Bakti, 2002, hlm.5

${ }^{2}$ V.D. Dudeja, Cyber Crimes and Law, volume 2, 2002, yang dikutip dari Barda Nawawi Arief, Antisipasi Hukum Pidana dan Perlindungan Korban Cyber Crime di Bidang Kesusilaan, makalah pada Seminar "Kejahatan Seks melalui Cyber Crime dalam Perspektif Agama, Hukum dan Perlindungan Korban", FH UNSWAGATI, di Hotel Zamrud Cirebon, 20 Agustus 2005, hlm. 1

${ }^{3}$ Data Protection Working Party, Council of Europe, Opinion 4/2001 On the Council of Europe's Draft Convention on Cyber Crime”, adopted on 22 March 2001, 500/01/EN/Final WP. 41, p.2
} 
Perkembangan cyber crime sebagai bentuk kejahatan di dunia cyber space telah $^{4}$ menggejala secara global sebagai bayangan gelap (a dark shadow) kemajuan teknologi di bidang komunikasi dan informasi, karena memungkinkan terjadinya bentuk-bentuk eksploitasi baru, kesempatan baru untuk aktifitas kejahatan, dan bahkan bentuk-bentuk baru dari kejahatan.

Salah satu masalah cyber crime yang juga sangat meresahkan dan mendapat perhatian berbagai pihak adalah masalah cyber crime di bidang kesusilaan. Jenis cyber crime di bidang kesusilaan yang sering diungkapkan adalah cyber pornography (khususnya child pornography) dan cyber sex. ${ }^{5}$

Di internet atau dunia maya sangat mudah ditemukan bahan-bahan pornografi atau yang berkaitan dengan masalah seksual, seperti yang dikemukakan oleh Mark Griffihs bahwa sex merupakan topik yang paling populer di internet (the most popular topic on the internet). ${ }^{6}$ Menurut perkiraan $40 \%$ dari berbagai situs di WWW menyediakan bahan-bahan seperti itu. ${ }^{7}$ Senada dengan hal tersebut, Nathan Tabor mengatakan statistik menunjukan bahwa $25 \%$ dari semua internet, mesin pencarinya minta dihubungkan dengan pornografi ${ }^{8}$ dan diperkirakan $20 \%$ dari pemakai internet mengunjungi situs cybersex dan terlibat dalam kegiatan ini. ${ }^{9}$

Penyalahgunaan internet di dunia maya kini belum ada peraturan perundangundangan yang mengaturnya secara khusus, terlebih yang dikaitkan dengan perbuatan asusila atau seks. Padahal di dunia cyber masalah yang berhubungan dengan seks menimbulkan berbagai permasalahan dalam aspek hukum, moral dan agama.

Cybersex terkait dengan seks, jasa, dan aktivitas menyertakan internet di dalamnya. Cyber dalam konteks ini adalah suatu kata kerja, yang mengacu pada tindakan menikmati cybersex, dalam defenisi yang paling tegas dan pendek cybersex adalah suatu kombinasi antara komunikasi dan masturbasi (a combination of communication and masturbation). Ini

\footnotetext{
${ }^{4}$ Menurut Howard Rheingold bahwa cyber space adalah sebuah ruang imajinar atau ruang maya yang bersifat artificial, di mana setiap orang melakukan apa saja yang bisa dilakukan dalam kehidupan sosial sehari-hari dengan cara-cara baru. Istilah cyber space ini lahir dari William Gibson seorang penulis fiksi ilmiah (science fiction), kata cyber space ditemukan dalam novelnya yang berjudul Veiwomancerdan Virtula Light, Lihat Abdul Wahid, Kejahatan Mayantara, Bandung: Refika Aditama, 2005, hlm. 32

${ }^{5}$ Barda Nawawi Arief, Antisipasi Hukum Pidana, Op.Cit., hlm. 2

${ }^{6}$ Mark Griffiths, Sex on The Internet: Observations and Implications for Internet sex Addiction, Journal of Sex Research, November 2001, mark.griffith@ntu.ac.uk

${ }^{7}$ Gloria G. Brame, How to Have Cyber Sex: Boot Up and Turn On, tersedia pada http://www.gloriabrame.com/glory/journ.html diakses tanggal 20 Mei 2019

${ }^{8}$ Nathan Tabor, Adultary is Killing the American Family, tersedia pada http://theconervativevoice.com diakses tanggal 20 Mei 2019

${ }^{9}$ Marlene M Maheu, The Future of Cyber Sex and Relationship Fidelity, http://www.selfhelpmagazine.com diakses tanggal 20 Mei 2019
} 
merupakan suatu kepuasan seksual bagi seseorang yang berkhayang dengan orang lain. Hampir serupa dengan telepon seks, perbedaan yang menonjol hanyalah sebutan metode komunikasi. ${ }^{10}$

Banyak akibat negatif yang ditimbulkan dari cyber sex, bahkan ada yang sudah mengklasifikasikannya sebagai bentuk baru perzinahan. Melihat fakta tersebut maka perlu dilakukan pengkajian serius dan konseptual terhadap kebijakan penanggulangannya. Tidak adanya pengaturan yang tegas dan jelas dalam bidang hukum mengenai cybersex menyebabkan makin maraknya perbuatan tersebut, sehingga dirasa perlu dicari bentuk aturan hukumnya yang tepat.

\section{B. Permasalahan}

Teknologi internet semakin populer setiap harinya. Teknologi yang semakin merambah ke segenap lapisan masyarakat di seluruh belahan dunia ini sekan membuka pintu ke mana saja bagi penggunanya. Mulai dunia informasi, dunia hiburan, termasuk di dalamnya dunia seks. Perkembangan teknologi informasi mengakibatkan modus operandi delik kesusilaan mengalami perkembangan, semula hanya sebatas perbuatan kesusilaan atau sex secara fisik, namun kini telah berkembang ke arah non fisik seperti cybersex.

Selanjutnya, bukan hal baru jika dikatakan bahwa media porno juga menyumbangkan peranan besar dalam terjadinya tindak pidana, khususnya perkosaan. Cybersex sebagai salah satu media pornografi pun dapat dipastikan termasuk sebagai faktor pemicu tindak pidana tersebut. Berkaitan dengan masalah kejahatan yang berbasis teknologi, ternyata pernah terjadi kekosongan hukum karena kesulitan dalam merumuskan delik dan ketidakmampuan hukum pidana positif mengejar perkembangan ilmu pengetahuan dan teknologi (IPTEK) hingga munculnya Undang-Undang Nomor 11 Tahun 2008 tentang Informasi dan Transaksi Elektronik yang telah disahkan pada tanggal 21 April 2008 yang diikuti dengan peraturan pelaksanaannya yaitu Peraturan Presiden Nomor 10 Tahun 2008 tentang Penggunaan Sistem Elektronik dalam Kerangka Indonesia National Single Window. Oleh karena itu, dalam penulisan ini hanya terbatas pada ruang lingkup yang berkaitan dengan cybersex dengan perumusan masalah sebagai berikut:

\footnotetext{
${ }^{10}$ Cyber in this context is adverb, it refers to the act of having cyber sex, which in it's shortest and most explicit definition, cyber sex is a combination of communication and masturbation. It is a selfish gratification of one's sexual desires while sharing one's most intimate thoughts and fantasies with someone else. It is nearly indentical to phone sex, the only difference being the method of communication, cybersex there are organizations out there to help you. The cyber AA Discussion Board, http://www.salagram.net/cyber.html diakses tanggal 20 Mei 2019
} 
1. Bagaimana pengaturan hukum pidana saat ini dalam menanggulangi kejahatan di bidang cybersex?

2. Bagaimana pengaturan hukum pidana yang akan datang untuk penanggulangan kejahatan di bidang cybersex?

\section{Kerangka Teoretis}

Menurut Soedarto, politik hukum adalah usaha untuk mewujudkan peraturanperaturan yang baik dengan situasi dan kondisi tertentu. Secara mendalam dikemukakan juga bahwa politik hukum merupakan kebijakan negara melalui alat-alat perlengkapannyaa yang berwenang untuk menetapkan peraturan-peraturan yang dikehendaki dan diperkirakan dapat digunakan untuk mengekspresikan apa yang terkandung dalam masyarakat dalam rangka mencapai apa yang dicita-citakan. ${ }^{11}$

Senada dengan pernyataan di atas, Solly Lubis ${ }^{12}$ juga menyatakan bahwa politik hukum adalah kebijakan politik yang menentukan peraturan hukum apa yang seharusnya berlaku mengatur berbagai hal kehidupan bermasyarakat dan bernegara. Mahfud MD juga memberikan definisi politik hukum sebagai kebijakan mengenai hukum yang akan atau telah dilaksanakan secara nasional oleh pemerintah. Hal ini juga mencakup pula pengertian tentang bagaimana politik mempengaruhi hukum dengan cara melihat konfigurasi kekuatan yang ada di belakang pembuatan dan penegakan hukum itu. Dalam konteks ini hukum tidak bisa hanya dipandang sebagai pasal-pasal yang bersifat imperatif, melainkan harus dipandang sebagai subsistem yang dalam kenyataannya bukan tidak mungkin sangat ditentukan oleh politik, baik dalam perumusan materinya (pasal-pasal), maupun dalam penegakannya. $^{13}$

Berdasarkan pengertian tentang politik hukum sebagaimana dikemukakan di atas, maka secara umum dapat ditarik kesimpulan bahwa politik hukum pidana merupakan upaya menentukan ke arah mana pemberlakuan hukum pidana Indonesia masa yang akan datang dengan melihat penegakannya saat ini. Hal ini juga berkaitan dengan konseptualisasi hukum pidana yang paling baik untuk diterapkan. ${ }^{14}$

Lebih lanjut Soedarto mengungkapkan bahwa melaksanakan politik hukum pidana berarti mengadakan pemilihan dalam rangka mencapai hasil perundang-undangan pidana

\footnotetext{
${ }^{11}$ Mahmud Mulyadi, Criminal Policy: Pendekatan Integral Penal Policy dan Non Penal Policy dalam Penanggulangan Kejahatan Kekerasan. Medan: Pustaka Bangsa Pers, 2008, hlm. 65-66

${ }^{12}$ Ibid

${ }^{13} \mathrm{Ibid}$

${ }^{14}$ Ibid
} 
yang paling baik dengan memenuhi syarat keadilan dan dayaguna. ${ }^{15}$ Marc Ancel menyatakan politik hukum pidana merupakan suatu ilmu sekaligus seni yang mempunyai tujuan praktis untuk memungkinkan peraturan hukum positif dirumuskan secara lebih baik dan untuk memberi pedoman kepada pembuat undang-undang, pengadilan yang menerapkan undang-undang dan kepada para pelaksana putusan pengadilan. ${ }^{16} \mathrm{~A}$. Mulder mengemukakan secara rinci tentang ruang lingkup politik hukum pidana yang menurutnya bahwa politik hukum pidana adalah garis kebijakan untuk menentukan: ${ }^{17}$

1. Seberapa jauh ketentuan-ketentuan pidana yang berlaku perlu dilakukan perubahan atau diperbaharui;

2. Apa yang dapat diperbuat untuk mencegah terjadinya kejahatan;

3. Cara bagaimana penyelidikan, penuntutan, peradilan dan pelaksanaan pidana harus dilaksanakan.

Definisi Mulder di atas bertolak dari pengertian "Sistem Hukum Pidana" menurut Marc Ancel yang mengatakan bahwa tiap masyarakat yang teroganisir memiliki sistem hukum pidana yang terdiri dari:

(a) Peraturan-peraturan hukum pidana dan sanksinya;

(b) Suatu prosedur hukum pidana; dan

(c) Suatu mekanisme pelaksanaan pidana ${ }^{18}$.

Usaha dan kebijakan untuk membuat peraturan hukum pidana yang baik pada hakekatnya tidak dapat dilepaskan dari tujuan penanggulangan kejahatan. Jadi, kebijakan atau politik hukum pidana juga merupakan bagian dari politik kriminal. Dengan perkataan lain, dilihat dari sudut politik kriminal, maka politik hukum pidana identik dengan pengertian "kebijakan penanggulangan kejahatan dengan hukum pidana."19

Upaya penanggulangan kejahatan dengan hukum pidana pada hakekatnya juga merupakan bagian dari usaha penegakan hukum (khususnya penegakan hukum pidana). Politik atau kebijakan hukum pidana dapat dikatakan merupakan bagian dari kebijakan penegakan hukum (law enforcement policy). Di samping itu, usaha penanggulangan kejahatan lewat pembuatan undang-undang (hukum) pidana pada hakekatnya juga merupakan bagian integral dari usaha perlindungan masyarakat (social welfare). Kebijakan

\footnotetext{
${ }^{15}$ Ibid

${ }^{16}$ M. Hamdan, Politik Hukum Pidana, Jakarta: Raja Grafindo, 1997, hlm.20

${ }^{17}$ Barda Nawawi Arief, Bunga Rampai Kebijakan Hukum) Pidana (Perkembangan Penyusunan Konsep KUHP Baru), Jakarta: Kencana Prenada Media Group, 2008, hlm. 23-24

${ }^{18}$ Ibid

${ }^{19}$ Ibid
} 
hukum pidana menjadi sangat wajar bila merupakan bagian dari kebijakan atau politik sosial (social policy). Kebijakan sosial dapat diartikan sebagai segala usaha yang rasional untuk mencapai kesejahteraan masyarakat dan sekaligus mencakup perlindungan masyarakat. Ini berarti pengertian social policy telah mencakup social welfare policy dan social defence policy. ${ }^{20}$

Berdasarkan dimensi di atas, kebijakan hukum pidana pada hakekatnya merupakan usaha untuk mewujudkan peraturan perundang-undangan pidana sesuai dengan keadaan pada waktu tertentu (ius constitutum) dan masa mendatang (ius constituendum). Konsekuensi logisnya, kebijakan hukum pidana identik dengan penal reform dalam arti sempit, karena sebagai suatu sistem, hukum terdiri dari budaya (cultural), sturktur (structural), dan substansi (substantive) hukum pidana, disamping memperbaharui perundang-undangan, juga mencakup pembaharuan ide dasar dan ilmu hukum pidana. ${ }^{21}$

Pada hakekatnya, kebijakan hukum pidana (penal policy, criminal policy atau strafrechtspolitiek) merupakan proses penegakan hukum pidana secara menyeluruh atau total. Menurut Wisnubroto, kebijakan hukum pidana merupakan tindakan yang berhubungan dalam hal-hal $:^{22}$

a. Bagaimana upaya pemerintah untuk menanggulangi kejahatan dengan hukum pidana;

b. Bagaimana merumuskan hukum pidana agar dapat sesuai dengan kondisi masyarakat;

c. Bagaimana kebijakan pemerintah untuk mengatur masyarakat dengan hukum pidana;

d. Bagaimana menggunakan hukum pidana untuk mengatur masyarakat dalam rangka mencapai tujuan yang lebih besar.

Berdasarkan pengertian politik hukum pidana yang dikemukakan diatas baik oleh A. Mulder maupun yang lain, maka ruang lingkup kebijakan hukum pidana ini sesungguhnya meliputi masalah yang cukup luas, yaitu meliputi evaluasi terhadap substansi hukum pidana pada masa yang berlaku saat ini untuk pembaharuan substansi hukum pidana pada masa yang akan datang, dan bagaimana penerapan hukum pidana ini melalui komponen Sistem Peradilan Pidana, serta yang tidak kalah pentingnya adalah upaya pencegahan terhadap kejahatan. Upaya pencegahan ini berarti bahwa hukum pidana juga harus menjadi salah satu

\footnotetext{
${ }^{20} \mathrm{Ibid}$, hlm. 25

${ }^{21}$ Llilik Mulyadi, Bunga Rampai Hukum Pidana: Perspektif, Teoretis dan Praktek, Bandung: PT. Alumni, 2008, hlm. 390

${ }^{22}$ Ibid, hlm. 391
} 
instrumen pencegah kemungkinan terjadinya kejahatan. Ini juga berarti bahwa penerapan hukum pidana harus mempunyai pengaruh yang efektif untuk mencegah sebelum suatu kejahatan terjadi. ${ }^{23}$

Menurut Lawrence Meir Friedman terdapat tiga unsur dalam sistem hukum, yakni: ${ }^{24}$

(1) Struktur Hukum ( Legal Structure),

Substansi juga berarti produk yang dihasilkan oleh orang yang berada dalam sistem hukum yang mencakup hukum yang hidup (living law), bukan hanya aturan yang ada dalam kitab undang-undang (law books). ${ }^{25}$ Idealnya tatanan hukum nasional mengarah pada penciptaan sebuah tatanan hukum nasional yang menjamin penyelenggaraan negara dan relasi antara warga negara, pemerintah dan dunia internasional secara baik. Tujuan politik hukum yaitu menciptakan sebuah sistem hukum nasional yang rasional, transparan, demokratis, otonom dan responsif terhadap perkembangan aspirasi dan ekspetasi masyarakat, bukan sebuah sistem yang bersifat menindas, ortodoks dan reduksionistik. ${ }^{26}$ Substansi hukum berkaitan dengan proses pembuatan suatu produk hukum yang dilakukan oleh pembuat undang-undang. Nilai-nilai yang berpotensi menimbulkan gejala hukum di masyarakat dirumuskan dalam suatu peraturan perundang-undangan. Sedangkan pembuatan suatu produk perundang-undangan dipengaruhi oleh suasana politik dalam suatu negara.

Seringkali substansi hukum yang termuat di dalam suatu produk perundangundangan dipengaruhi oleh kepentingan-kepentingan kelompok tertentu. Sehingga hukum yang dihasilkan tidak responsif terhadap perkembangan masyarakat. Akibat yang lebih luas adalah hukum dijadikan sebagai alat kekuasaan dan bukan sebagai pengontrol kekuasaan atau membatasi kesewenangan yang sedang berkuasa.

Menurut Satjipto Rahardjo yang mengutip dari Radbruch, terdapat nilai-nilai dasar dari hukum, yaitu Keadilan, Kegunaan dan Kepastian hukum. ${ }^{27}$ Tidak jarang ketiga nilai dasar hukum tersebut saling bertentangan dalam penegakan hukum. Bila hal tersebut terjadi maka yang harus diutamakan adalah keadilan, mengingat tujuan hukum adalah terciptanya rasa keadilan di masyarakat. Peraturan perundangundangan yang tidak responsif dan demokratis hanya akan menimbulkan opini di masyarakat yang dapat menganggu stabilitas hukum, keamanan ekonomi dan politik. Sehingga untuk membentuk peraturan perundang-undangan yang sesuai dengan aspirasi yang berkembang di masyarakat harus bebas dari intervensi dan kepentingan pihak-pihak atau kelompok tertentu.

(2) Substansi (Legal Substance),

Struktur adalah kerangka atau rangkanya, bagian yang tetap bertahan, bagian yang memberi semacam bentuk dan batasan secara keseluruhan ${ }^{28}$. Struktur hukum merupakan institusionalisasi dalam keberadaan hukum. Struktur hukum di sini meliputi lembaga negara penegak hukum seperti Pengadilan, Kejaksaan, Kepolisian,

\footnotetext{
${ }^{23}$ Mahmud Mulyadi, Op. Cit, hlm. 67

${ }^{24}$ Achmad Ali, Keterpurukan Hukum di Indonesia Penyebab dan Solusinya, Cet. Ke.2, Ciawi Bogor: Ghalia Indonesia, 2005, hlm.1

${ }^{25}$ Ibid., hlm 2.

${ }^{26}$ Imam Syaukani, A. Ahsin Thohari, Dasar-dasar Politik Hukum, Jakarta: PT Rajagrafindo Persada, 2008, hlm. 72

${ }^{27}$ Satjipto Rahardjo, Ilmu Hukum, Cet. Ke 5, Bandung: PT Citra Aditya Bakti, 2000, hlm. 19

${ }^{28}$ Achmad Ali, Op.cit.
} 
Advokat $^{29}$ dan lembaga penegak hukum yang secara khusus diatur oleh undangundang. Sehingga dalam melaksanakan tugas dan tanggungjawabnya terlepas dari pengaruh kekuasaan pemerintah dan pengaruh-pengaruh lain.Terdapat adagium yang menyatakan fiat justitia et pereat mundus (meskipun dunia ini runtuh hukum harus ditegakan). Hukum tidak dapat berjalan atau tegak bila tidak ada aparat penegak hukum yang kredibilitas, kompeten dan independen. Seberapa bagusnya suatu peraturan perundang-undangan bila tidak didukung dengan aparat penegak hukum yang baik, maka keadilan hanya angan-angan.

\section{(3) Kultur Hukum (Legal Culture)}

Kultur hukum menurut Lawrence Meir Friedman adalah sikap manusia terhadap hukum dan sistem hukum-kepercayaan, nilai, pemikiran, serta harapannya. Kultur hukum adalah suasana pemikiran sosial dan kekuatan sosial yang menentukan bagaimana hukum digunakan, dihindari, atau disalahgunakan ${ }^{30}$. Hukum dipercaya sebagai suatu lembaga penyeimbang yang kuat terhadap ancaman disintegrasi dalam hidup bermasyarkat akbiat benturan kekuatan yang sama-sama ingin berkuasa dan sekaligus membatasi kesewenangan yang sedang berkuasa. Hukum dalam bentuknya yang asli bersifat membatasi kekuasaan dan berusaha untuk memungkinkan terjadinya keseimbangan dalam hidup bermasyarakat. Berbeda dengan kekuasaan yang agresif dan ekspansionis, hukum cenderung bersifat kompromistis, damai dan penuh dengan kesepakatan-kesepakatan dalam kehidupan sosial dan politik. ${ }^{31}$

Baik substansi hukum, struktur hukum maupun budaya hukum saling terkait antara satu dengan yang lain dan tidak dapat dipisahkan. Dalam pelaksanaannya di antara ketiganya harus tercipta hubungan yang saling mendukung agar tercipta pola hidup aman, tertib, tentram dan damai. Begitu juga dalam penegakan hukum, ketiga unsur ini memegang peranan yang signifikan untuk menciptakan penegakan hukum yang berorientasi pada keadilan sebagaimana yang dicita-citakan oleh sebagian besar para pencari kebenaran via pengadilan melalui lembaga penegakan hukum lainnya.

\section{Kerangka Konseptual}

\section{Pengertian dan Ruang Lingkup Kebijakan Kriminal}

Pengertian Kebijakan Kriminal atau politik kriminal merupakan usaha rasional dan terorganisasi dari suatu masyarakat untuk menanggulangi kejahatan. ${ }^{32}$ Dimana definisi ini diambil dari Marc Ancel yang merumuskan sebagai "the rational organization of the control

\footnotetext{
${ }^{29}$ Lihat, Soerjono Soekanto, Faktor-Faktor yang Mempengaruhi Penegakan Hukum, cet. Ke 10, Jakarta: PT Raja Grafindo Persada, 2011, hlm. 19

${ }^{30}$ Achmad Ali, Op.cit., hlm.2

${ }^{31}$ Peter Mahmud Marzuki, Pengantar Ilmu Hukum, Jakarta: Prenada Media Group, 2009, hlm. 83

${ }^{32}$ Sudarto, Hukum dan Hukum Pidana, Bandung: Alumni, 1981, hlm 38
} 


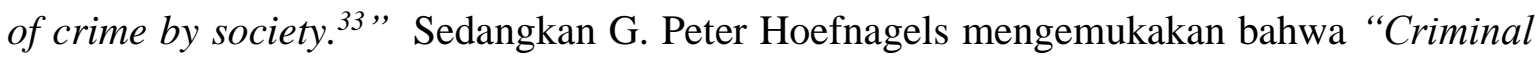
policy is the rational organization of the social reactions to crime." 34

Selanjutnya juga G. Peter Hoefnagels mengemukakan beberapa definisi mengenai kebijakan kriminal, antara lain:

1. Kebijakan kriminal adalah ilmu tentang reaksi dalam menghadapi kejahatan.

2. Kebijakan kriminal adalah ilmu untuk menanggulangi kejahatan.

3. Kebijakan kriminal adalah kebijakan untuk merancang tingkah laku manusia sebagai kejahatan.

4. Kebijakan kriminal adalah suatu rekasi terhadap kejahatan yang rasional. ${ }^{35}$

Menurut Sudarto, kebijakan kriminal mempunyai beberapa pengertian, antara lain:

1. Dalam arti sempit, mempunyai arti keseluruhan asas dan metode yang menjadi dasar dari reaksi terhadap pelanggaran hukum yang berupa pidana.

2. Dalam arti luas, mempunyai pengertian keseluruhan fungsi dari aparat penegak hukum, termasuk didalamnya cara bekerja dari pengadilan dan polisi.

3. Dalam arti paling luas, mempunyai arti keseluruhan kebijakan, yang dilakukan melalui perundang-undangan dan badan-badan resmi yang bertujuan untuk menegakan norma-norma sentral dari masyarakat. ${ }^{36}$

Dari definisi di atas, dapat diperoleh gambaran bahwa kebijakan merupakan usaha yang rasional dari masyarakat untuk mencegah kejahatan dan mengadakan reaksi terhadap kejahatan. Usaha yang rasional ini merupakan konsekuensi logis, karena menurut Sudarto, di dalam melaksanakan politik, orang mengadakan penilaian dan melakukan pemilihan dari sekian banyak alternatif yang dihadapi ${ }^{37}$.

Kebijakan kriminal atau penanggulangan kejahatan pada hakekatnya merupakan bagian integral dari upaya perlindungan masyarakat dan upaya mencapai kesejahteraan masyarakat oleh karena itu dapat dikatakan bahwa tujuan akhir dari politik kriminal adalah perlindungan masyarakat untuk mencapai kesejahteraan masyarakat. Dengan demikian dapatlah dikatakan, bahwa politik kriminal pada hakekatnya juga merupakan bagian integral dari politik sosial. ${ }^{38}$

Menurut G. Peter Hoefnagels upaya penanggulangan kejahatan perlu ditempuh dengan pendekatan kebijakan, yaitu adanya keterpaduan (integritas) antara upaya penanggulangan kejahatan dengan "penal" dan "non-penal". ${ }^{39}$ Hal ini dapat ditempuh dengan:

\footnotetext{
${ }^{33}$ Dalam Barda, Bunga Rampai Kebijakan Hukum Pidana, Bandung: Citra Aditya Bakti, 1996, hlm. 2

${ }^{34}$ G. Peter Hoefnagels, The Other Side of Criminology (An Inversion of the Concept of Crime), Holland: Kluwer-Deventer, 1969, hlm. 57

${ }^{35}$ Ibid. hlm 57, 99, 100

${ }^{36}$ Sudarto, Kapita Selekta Hukum Pidana, Bandung: Alumni, 1986, hlm. 113-114

${ }^{37}$ Sudarto, Hukum dan Hukum Pidana, Bandung: Alumni, 1986, hlm 153

${ }^{38}$ Barda Nawawi Arief, Op. Cit, hlm. 3

${ }^{39}$ Barda Nawawi Arief, Op. Cit., hlm. 4
} 
a. Penerapan hukum pidana (criminal law application)

b. Pencegahan tanpa pidana (prevention without punishment)

c. Mempengaruhi pandangan masyarakat mengenai kejahatan dan pemidanaan lewat media massa (influecing views of society on crime and punishment).

Penanggulangan kejahatan melalui jalur "non-penal" lebih bersifat tindakan pencegahan untuk terjadinya kejahatan, sehingga sasaran utamanya adalah menangani faktor-faktor kondusif terjadinya kejahatan. Faktor-faktor kondusif itu antara lain berpusat pada masalahmasalah atau kondisi-kondisi sosial yang secara langsung atau tidak langsung dapat menimbulkan atau menumbuh suburkan kejahatan.

Seperti yang telah dijelaskan sebelumnya bahwa kebijakan kriminal ini tidak bisa terlepas dari kebijakan yang lebih luas, yaitu kebijakan sosial (social policy) yang terdiri dari upaya-upaya untuk kesejahteraan sosial (social welfare policy) dan upaya-upaya untuk perlindungan masyarakat (social defence policy).

\section{Cyber Crime di Bidang Kesusilaan}

Secara singkat dapat dikatakan, bahwa delik kesusilaan adalah delik yang berhubungan dengan masalah kesusilaan, namun tidaklah mudah menetapkan batas-batas atau ruang lingkup delik kesusilaan, karena pengertian dan batas-batas kesusilaaan itu cukup luas dan dapat berbeda-beda menurut pandangan dan nilai-nilai yang berlaku di dalam masyarakat, ${ }^{40}$ sehingga pada dasarnya setiap delik atau tindak pidana merupakan delik kesusilaan.

Secara juridis, delik kesusilaan menurut KUHP yang berlaku saat ini terdiri dari 2 kelompok tindak pidana, yaitu kejahatan kesusilaan diatur dalam Bab XIV Buku II dan pelanggaran kesusilaan (diatur dalam Bab VI buku III). Kelompok kejahatan kesusilaan Pasal 281-330 KUHP, sedangkan pelanggaran kesusilaan menurut KUHP Pasal 532-554. Sementara jika diamati berdasarkan kenyataan sehari-hari, persepsi masyarakat tentang arti kesusilaan lebih condong kepada kelakuan yang benar atau salah khususnya dlam hubungan seksual (behaviour as to right or wrong especially ini relation to sexual matter). ${ }^{41}$

Telah dikemukakan di atas, bahwa orang bisa berbeda pendapat mengenai batasan pengertian dan ruang lingkup delik kesusilaan. Roeslan Saleh misalnya pernah mengemukakan, bahwa pengertian kesusilaan hendaknya tidak dibatasi pada pengertian

\footnotetext{
${ }^{40}$ Barda Nawawi Arief, Antisipasi Hukum Pidana, Op.Cit., hlm. 5

${ }^{41}$ Leden Marpaung, Kejahatan Terhadap Kesusilaan dan Masalah Prevensinya, Jakarta: Sinar Grafika, 1996, hlm. 110
} 
kesusilaan dalam bidang seksual, tetapi juga meliputi hal-hal lain yang termasuk dalam norma-norma kepatutan bertingkah laku dalam pergaulan masyarakat. Oleh karena itu beliau menyarankan agar tindak pidana berupa "meninggalkan orang yang perlu ditolong”, "penghinaan" dan "membuka rahasia" juga dimasukkan ke dalam "tindak pidana terhadap kesusilaan". ${ }^{42}$

Berbagai KUHP dari negara lain, pengelompokan delik kesusilaan juga berbedabeda dan tampaknya bergantung pada kesepakatan dan kebijakan pembuat undang-undang. ${ }^{43}$ Walaupun pengelompokan atau ruang lingkup delik kesusilaan bisa berbeda-beda, namun patut dicatat bahwa pendapat Roeslan Saleh yang menggarisbawahi pandangan Oemar Senoadji bahwa dalam menentukan isi (materi/substansi) harus bersumber dan mendapat sandaran kuat dari moral agama.

Penentuan delik kesusilaan juga harus berorientasi pada "nilai-nilai kesusilaan nasional" (NKN) yang telah disepakati bersama dan juga memperhatikan nilai-nialai kesusilaan yang hidup dalam masyarakat. NKN ini dapat digali antara lain dari produk legislatif nasional (berbentuk Undang-undang Dasar atau Undang-undang). Dalam struktur masyarakat Indonesia, NKN bersumber dari nilai-nialai agama dan kesusilaan yang hidup di tengah-tengah masyarakat. ${ }^{44}$

Sesuai dengan pendapat di atas tentang batasan dan ruang lingkup tindak pidana kesusilaan sebagaimana terurai di atas. Mulyana W Kusuma juga menyatakan bahwa kejahatan seks serta kejahatan yang menyangkut serta kejahatan yang menyangkut seks (sex related crimes) yang dirumuskan dalam hukum pidana sebagai delik susila senantiasa harus dipahami secara kontekstual dalam hubungannya dengan perkembangan budaya dan perubahan-perubahan stuktur sosial yang ada di masyarakat. ${ }^{45}$

Perkembangan teknologi informasi dalam hal internet telah mengakibatkan perubahan di tengah masyarakat. Sistem tata nilai di dalam suatu masyarakat berubah dari yang bersifat local particular menjadi global universal. Hal ini pada akhirnya akan membawa dampak pada pergeseran nilai dan norma khususnya norma hukum dan kesusilaan.

\footnotetext{
${ }^{42}$ Roeslan Saleh, Bab-Bab Kodifikasi Hukum Pidana (Buku II), dalam Lokakarya diselenggarakan oleh BPHN Departemen Kehakiman, tanggal 23-25 April 1985 di Jakarta

${ }^{43}$ Barda Nawawi Arief, Bunga Rampai Kebijakan Hukum Pidana, Op. cit

${ }^{44}$ Barda Nawawi Arief, Antisipasi Hukum Pidana, Op. Cit, hlm. 7

45 Mulyana W. Kusuma, Perumusan Tindak Pidana Kesusilaan (Perzinahan dan Pemerkosaan) dalam Rancangan KUHP Baru Ditinjau dari Aspek Kebijakan Kriminal dan Aspek Sosial dan Budaya, Makalah disajikan dalam Seminar sehari tentang Tinjauan Rancangan KUHP Baru Khususnya Tindak Pidana Kesusilaan, Fakultas Hukum Universitas Katolik Soegihapranata, Semarang 20 Febuari 1993, hlm.1
} 
Kemajuan teknologi ternyata tidak digunakan sebagai sarana positif untuk meningkatkan kualitas kehidupan, tetapi justru digunakan sebagai sarana negatif yang dapat membawa dampak negatif. Keprihatian terhadap dampak negatif dari teknologi maju tersebut pernah dikemukakan oleh Art Bowker, seorang ahli Computer Crime dari Amerika yang menyatakan bahwa teknologi maju telah meningkat menjadi way of life masyarakat kita, tetapi sangat disayangkan teknologi maju ini menjadi alat atau sarana pilihan bagi para pelaku cybersex (cybersex offender). ${ }^{46}$

Berbagai delik kesusilaan yang dikemukakan di atas, dapat juga terjadi di ruang maya (cyber space), terutama yang berkaitan dengan masalah pornografi, muncikari/calo, dan pelanggaran kesusilaan/percabulan/perbuatan tidak senonoh/zina. Semakin maraknya pelanggaran kesusilaan di dunia cyber ini, terlihat dengan munculnya berbagai istilah seperti: cyber pornography (khususnya child pornography), on-line pornography, cyber sex, cyber sexer, cyber lover, cyber romance, cyber affair, on-line romance, sex on-line, cybersex addicts, cyber sex offender.

\section{Pengertian Cybersex}

Menurut Peter David Goldberg, cybersex adalah penggunaan internet untuk tujuantujuan seksual (the use of the internet for sexual purpose). ${ }^{47}$ Senada dengan ini, David Greenfield mengemukakan, bahwa cybersex adalah menggunakan komputer untuk setiap bentuk ekspresi atau kepuasan seksual (using the computer for any form of sexual expression of gratification). Lebih lanjut dijelaskan bahwa cybersex dapat dipandang sebagai kepuasan atau kegembiraan maya dan suatu bentuk baru dari keintiman. ${ }^{48}$ Patut dicatat, bahwa hubungan intim dapat juga mengandung arti "hubungan seksual atau perzinahan". ${ }^{49}$ Ini berarti, cybersex merupakan bentuk baru dari perzinahan.

Dalam ensiklopedia bebas Wikipedia dinyatakan, bahwa cybersex atau computersex adalah "pertemuan sex secara virtual/maya antara dua orang atau lebih yang terhubung melalui

\footnotetext{
46 Art Bowker and Michael Gray, An Introduction to the Supervision of the Cybersex Offender, http://uscourt.gov diakses tanggal 21 Mei 2019

Publishing Information: Advanced Technologies are increasingly becoming a way of life for our society. Computers are found in every home, school, and business, with more and more individuals going "online" every day. Unfortunately, these advanced technologies (computers, scanners, digital cameras, the internet, etc) are becoming the tool of choice for the "cybersex offender."

${ }^{47}$ Peter David Goldberg, An Explonatory Study About the Impacts that Cybersex (the use of the Internet for sexual purpose) is Having on Families and The Practices of Marriage and Family Therapists, 2004, (pedrogoldberg@aol.com)

${ }^{48}$ Dalam Gloria G. Brame, Loc. Cit http://gloria-brame.com/glory/journ7.html diakses tanggal 21 Mei 2019

${ }^{49}$ Lihat John M. Echols dan Hassan Shadily, kamus Inggris Indonesia, 2000, hlm.328. Dalam Kamus Hornby, 1963, hlm. 517 disebut dengan istilah "illicit sexual relations"
} 
jaringan internet dengan mengirimkan pesan-pesan seksual yang menggambarkan suatu pengalaman seksual". Cybersex atau computersex merupakan bentuk permainan peran antara para partisipan yang berpura-pura atau menganggap dirinya melakukan hubungan seksual secara nyata, dengan menggambarkan sesuatu untuk mendorong fantasi seksual mereka. Cybersex ini terkadang disebut juga dengan "cybering". ${ }^{50}$ Menurut Greenfield dan Orzack, cybering ini dimasukan dalam penggolongan cybersex yang berupa online sesual activity (OSA) karena dengan cybering itu, salah seorang atau kedua orang yang saling berfantasi itu dapat melakukan masturbasi (onani), ${ }^{51}$ bahkan menurut Kenneth Allen " $A n$ important and major element of cybersexual activity is masturbation. ". 52

Pengertian cybering atau sex on the internet dikemukakan pula oleh Michael G. Conner, sebagai “diskusi seksual secara online dengan tujuan mencapai orgasme (puncak syahwat). ${ }^{53}$

\section{PEMBAHASAN}

\section{A. Kebijakan Pidana Dalam Penanggulangan Cyber Crime di Bidang Kesusilaan}

Dilihat dari sudut "criminal policy" upaya penanggulangan kejahatan (termasuk penanggulangan cybersex) tentunya tidak dapat dilakukan secara parsial dengan hukum pidana (secara penal), tetapi harus ditempuh pula dengan pendekatan integral/sistemik. Sebagai salah satu bentuk dari hitech crime, adalah wajar bila upaya penanggulangan cybersex juga harus ditempuh dengan pendekatan teknologi (techno prevention). Di samping itu diperlukan pula pendekatan budaya/kultural, pendekatan moral/edukatif (terlebih untuk delik kesusilaan), dan bahkan pendekatan global (kerjasama internasional) karena cybersex dapat melampaui batas-batas negara (bersifat transnasional/transborder).

\footnotetext{
${ }^{50}$ Wikipedia the free encyclopedia, (en.wikipedia.org/wiki/Cybersex): cybersex or computersex is a vitrual sex encounter in which two or more persons connected remotely via a computer network send one another sexually explicit messages describing a sexual experience, by describing their actions and responding to their chat partners in a mostly written form design to stimulate their own sexual feelings and fantasies, .... It is a form of role-playing in which the participants pretend they are haaaving actual sexual intercourse, .... Cybersex is sometimes colloquially called "cybering"

${ }^{51}$ Peter D. Goldberg, Op. Cit.; Greenfield dan Orzack mendefinisikan "cybering” sebagai "direct use by two people who share the same fantasy while one or both masturbate."

52 Kenneth Allen, Cyber-Sex A Review and Implications of the Situation, (home.earthlink.net) diakses tanggal 21 Mei 2019

${ }^{53}$ Micheal G Conner, Psy.D, Internet Addiction \& Cyber Sex (www.CrisisCounseling.org) : Cybering or sex on the internet, is defined as the consensual sexual discussion online for the purpose of achieving a'ousal or an orgasm diakses tanggal 21 Mei 2019
} 
Menyadari bahwa penanggulangan kejahatan harus ditempuh melalui pendekatan/kebijakan integral, maka kebijakan penanggulangannya pun seharusnya melibatkan berbagai instansi departemen secara integral.

Walaupun sarana penal mempunyai keterbatasan, namun dilihat dari sudut perencanaan kebijakan penanggulangan kejahatan dengan hukum pidana, tahap kebijakan legislasi formulasi merupakan tahap paling strategis. Kesalahan/kelemahan kebijakan legislatif merupakan kesalahan strategis yang dapat menjadi penghambat upaya pencegahan dan penanggulangan kejahatan pada tahap aplikasi dan eksekusi.

Ketentuan hukum pidana positif yang terkait dengan tindak pidana di bidang kesusilaan, antara lain terdapat dalam:

a. Kitab Undang-Undang Hukum Pidana

- Melanggar kesusilaan secara terbuka (Pasal 281)

- Menyiarkan, mempertunjukan, membuat, menawarkan dan sebagainya, tulisan, gambar, benda yang melanggar kesusilaan/bersifat porno (Pasal 282-283)

- Perzinaan dan hal-hal lain yang berhubungan dengan melakukan atau menghubungkan/memudahkan perbuatan cabul dan hubungan seksual (Pasal 284-296)

- Mengungkapkan/mempertunjukan sesuatu yang bersifat porno atau yang mampu membangkitkan/merangsang nafsu birahi (Pasal 532-533)

Kelemahan dari ketentuan KUHP antara lain, berkaitan dengan jurisdiksi teritorial dan subyek hukum koorporasi

b. Undang-Undang Nomor 36 Tahun 1999 tentang Telekomunikasi

Ketentuan pidana dalam UU No. 36 Tahun 1999 diatur dalam Bab VII mulai dari Pasal 47 sampai Pasal 57, namun sangat disayangkan tindak pidana dalam UU tersebut lebih tertuju pada perlindungan jaringan telekomunikasi, alat dan penggunaannya, bukan terhadap muatan/materi informasi yang dikirim atau diterima, khususnya yang terkait dengan masalah kesusilaan. Padahal di dalam Pasal 21 ada ketentuan yang menyatakan:

\section{Penyelenggara telekomunikasi dilarang melakukan kegiatan usaha penyelenggaraan telekomunikasi yang bertentangan dengan kepentingan umum, kesusilaan, keamanan, atau ketertiban umum.}

Pelanggaran terhadap Pasal 21 itu hanya dikenakan sanksi administrasi pencabutan izin setelah mendapat peringatan tertulis (Pasal 45 jo. 46). Jadi tidak dijadikan tindak 
pidana, karena tidak termasuk dalam perumusan delik dalam Pasal 47 sampai Pasal 57. Tidak adanya perumusan delik terhadap pelanggaran pasal $21 \mathrm{itu}$, sangat berbeda dengan UU Pers yang mengancam pidana terhadap perusahaan pers yang memuat iklan melanggar kesusilaan.

c. Undang-Undang Nomor 40 Tahun 1999 tentang Pers

- Pasal 5 (1) : Pers nasional berkewajiban memberitakan peristiwa dan opini dengan menghormati norma-norma agama dan rasa kesusilaan masyarakat serta asas praduga tak bersalah.

- Pasal 13 : Perusahaan pers dilarang memuat iklan antara lain: (a) yang berakibat merendahkan martabar suatu agama dan atau mengganggu kerukunan hidup antar umat beragama, serta bertentangan dengan rasa kesusilaan masyarakat.

- Pasal 18 (2): perusahaan pers yang melanggar ketentuan pasal 5 ayat (1) dan pasal 13 dipidana dengan pidana denda paling banyak Rp. 500.000.000,00 (lima ratus juta rupiah).

Kelemahannya tidak ada kualifikasi delik dan tidak ada aturan pertanggungjawaban pidana koorporasi. Ada perumusan delik terhadap perusahaan pers yang diancam pidana denda; namun tidak ada aturan tentang:

- Kapan (dalam hal bagaimana) kooporasi/perusahaaan pers melakukan tindak pidana;

- Bagaimana koorporasi (perusahaan pers) yang tidak membayar denda (tidak ada aturan pidana pengganti dendanya).

d. Undang-Undang Nomor 32 Tahun 2002 tentang Penyiaran

- Pasal 57 jo. 36 ayat (5) mengancam pidana terhadap siaran yang (antara lain) menonjolkan unsur cabul. Ancaman pidananya:

- Penjara paling lama 5 (lima) tahun dan/atau denda paling banyak Rp. 1.000.000.000,00 (satu milyar rupiah) untuk penyiaran radio, dan:

- Dipidana dengan pidana penjara paling lama 5 (lima) tahun dan/atau denda paling banyak Rp. 10.000.000.000,00 (sepuluh miliar rupiah) untuk penyiaran televisi.

- Pasal 57 jo. 36 ayat (6) mengancam pidana terhadap siaran yang memperolokkan, merendahkan, melecehkan dan/atau mengabaikan nilainilai agama, martabat manusia Indonesia. 
- Pasal 58 jo. 46 ayat (3) mengancam pidana terhadap siaran (iklan niaga) yang di dalamnya memuat (antara lain):

- Hal-hal yang bertentangan dengan kesusilaan masyarakat dan nilai-nilai agama; dan/atau

- Eksploitasi anak di bawah umur 18 tahun

Ancaman pidananya:

- Penjara paling lama 2 (dua) tahun dan/atau denda paling banyak Rp. 500.000.000,00 (lima ratus juta rupiah) untuk penyiaran radio dan penjara paling lama 2 (dua) tahun dan/atau denda paling banyak Rp. 5.000.000.000,00 (lima miliar rupiah) untuk penyiaran televisi.

Ketentuan di atas dapat ditujukan kepada cyber crime di bidang kesusilaan, karena menurut undang-undang tersebut, yang dimaksud dengan

- Penyiaran adalah kegiatan pemacarluasan melalui sarana pemancaran dan/atau sarana tranmisi di darat, di laut, atau di antariksa dengan menggunakan spektrum frekuensi radio melalui udara, kabel, dan/atau media lainnya untuk dapat diterima secara serentak dan bersamaan oleh masyarakat dengan perangkat penerima siaran.

- Siaran adalah pesan atau rangkaian pesan dalam bentuk suara, gambar, atau suara dan gambar atau yang berbentuk grafis, karakter, baik yang bersifat interaktif maupun tidak, yang dapat diterima melalui perangkat penerima siaran.

- Siaran iklan niaga adalah siaran iklan komersial yang disiarkan melalui penyiran radio atau televisi dengan tujuan memperkenalkan, memasyaratkan, dan/atau mempromosikan barang atau jasa kepada khalayak sasaran untuk mempengaruhi konsumen agar menggunakan produk yang ditawarkan.

Walaupun UU No. 32 Tahun 2002 di atas dapat digunakan untuk menjaring cyber crime di bidang kesusilaan yang berkaitan dengan delikdelik penyiaran, namun kelemahan jurisdiksi teritorial dalam KUHP sebagaimana dikemukakan di atas juga berlaku untuk undang-undang ini. Di samping itu, kelemahan lainnya ialah: tidak adanya kualifikasi delik tentang pertanggungjawaban pidana koorporasi, padahal delik- 
delik penyiaran dan iklan sangat terkait erat dengan koorporasi. Menurut pasal 14 dan 16 UU No. 32 Tahun 2002, lembaga penyiaran berbentuk badan hukum.

Kelemahan lainnya, delik-delik di atas hanya terbatas pada siaran melalui radio atau televisi; tidak mencakup penyiaran di bidang teknologi digital, satelit, internet, dan bentuk-bentuk khusus lain; padahal banyak siaran dan iklan niaga dalam situs cybersex dan cyberporn.

Di samping kelemahan-kelemahan dari perundang-undangan di atas, masih banyak kelemahan perundang-undangan saat ini dalam menghadapi masalah cyber crime (khususnya cybersex). Salah satunya, kelemahan formal di bidang alat bukti. Pengakuan juridis terhadap electronic record sebagai alat bukti hanya ada pada Undang-Undang Korupsi dan Undang-Undang Pencucian Uang (Pasal 26A UU No. 20 Tahun 2001; Pasal 38 UU No. 15 Tahun 2002; dan Pasal 44 (2) UU No. 30 Tahun 2002), sehingga menjadi masalah untuk tindak pidana lainnya, khususnya yang terkait dengan cyber crime.

\section{B. Kebijakan Penanggulangan (Penegakan Hukum) Dengan Hukum Pidana Positif Terhadap Cybersex}

Kebijakan penegakan hukum pidana terhadap delik-delik kesusilaan terkesan kurang mendapat prioritas, dibandingkan dengan upaya pemberantasan tindak pidana lainnya seperti korupsi, narkoba dan terorisme. Lemahnya penegakan hukum pidana terhadap delik kesusilaan di bidang cyber ini, mungkin berkaitan erat dengan lemahnya kebijakan perundang-undangan yang ada seperti dikemukakan di atas. Oleh karena itu perlu dilakukan kajian evaluatif dan reformatif/inovatif/rekonstruktif untuk mengefektifkan penegakan hukum pidana dalam masalah ini.

Walaupun sarana penal pada umumnya dan khususnya peraturan perundangundangan yang dikemukakan di atas mengandung kelemahan, namun seyogyanya dapat diefektifkan penerapannya terhadap masalah cybersex. Terlebih para pakar di internet menyatakan, bahwa cybersex pada hakikatnya sama dengan delik kesusilaan yang sesungguhnya (zina atau pelanggaran kesusilaan lainnya).

Berdasarkan pengertian cybersex yang telah dikemukakan di atas, dapat diidentifikasikan adanya pendapat, bahwa cybersex/computer sex adalah:

a. Penggunaan internet untuk tujuan-tujuan seksual;

b. Penggunaan komputer untuk setiap bentuk ekspresi atau kepuasan seksual; 
c. Merupakan bentuk baru dari keintiman, yang dapat juga diartikan sebagai bentuk baru dari perzinahan atau hubungan seksual yang gelap/haram/melanggar hukum (illicit sexual relations);

d. Dapat dipandang sebagai bentuk ekspresi atau kepuasan seksual maya

e. Merupakan bentuk pertemuan seks secara vitual/maya atau sex-online;

f. Pertemuan dua orang atau lebih yang terhubung melalui jaringan internet dengan mengirimkan pengalaman seksual untuk membangkitkan rangsangan/perasaan/fantasi seksual, sehingga terjadi masturbasi (onani);

g. Dilihat dari sudut akibatnya, banyak dampak negatif bagi si pelaku sendiri, merusak harmonisasi sistem kekeluargaan, dan merusah atau membahayakan anak-anak.

Mengamati hal-hal di atas, nampaknya cybersex sulit dijangkau oleh hukum pidana positif saat ini, karena perbuatannya bersifat maya dan sangat individual. Walaupun dinyatakan di atas, bahwa cybersex merupakan bentuk lain dari perzinahan atau hubungan seksual gelap/haram/melanggar hukum, namun sulit dijaring dengan Pasal 284 KUHP jika pengertian zina selalu dikaitkan pada adanya hubungan seksual atau persetubuhan secara fisik. Inilah salah satu kelemahan hukum pidana konvensional saat ini yang selalu bertolak dari paradigma perbuatan dalam arti fisik.

Pada tahun 2008, Pemerintah Indonesia dalam rangka menyempurnakan perundangundangan dalam memberantas cybersex mengeluarkan dua undang-undang baru yaitu:

a. Pengaturan Undang-Undang Nomor 11 Tahun 2008 tentang Informasi dan Transaksi Elektronik

Pada tahun 2008 akhirnya Indonesia memiliki peraturan perundang-undangan yang memuat larangan penyebaran cybersex dalam bentuk informasi elektronik, yakni Undang-Undang Nomor 11 Tahun 2008 tentang Informasi dan Transaksi Elektronik (UU ITE). Aturan tersebut terdapat pada Pasal 27 Ayat 1 Undang-Undang Nomor 11 Tahun 2008 yang berbunyi:

"Setiap orang dengan sengaja dan tanpa hak mendistribusikan dan/atau mentransmisikan dan/atau membuat dapat diaksesnya Informasi Elektronik dan/atau Dokumen Elektronik yang memiliki muatan yang melanggar kesusilaan."

Sanksi pidana akan dikenakan bagi setiap orang yang melakukan perbuatan seperti yang dinyatakan dalam Pasal 27 Ayat 1 yakni pidana paling lama 6 (enam) tahun dan/atau denda paling banyak Rp. 1.000.000.000,00 (satu miliar rupiah).

Pasal 27 Ayat 1 UU Nomor 11 Tahun 2008 ini menggunakan kata "dapat diaksesnya" yang berarti setiap orang dengan sengaja dan tanpa hak membuat dapat diaksesnya informasi elektronik bermuatan pornografi atau pelanggaran kesusilaan akan terkena sanksi pidana. 
Dalam Undang-Undang Nomor 11 Tahun 2008, juga diatur larangan mengubah atau memanipulasi informasi elektronik sehingga seolah-olah tampak asli. Kita sering mendengar dan melihat berita tentang tindak kriminal dari pelaku rekayasa foto. Kegiatan merekayasa foto termasuk perbuatan yang dilarang dalam Undang-Undang Nomor 11 Tahun 2008 terkait Pasal 35, yaitu:

"Setiap orang dengan sengaja dan tanpa hak atau melawan hukum melakukan manipulasi, penciptaan, prubahan, penghilangan, pengrusakan informasi elektronik dan/atau dokumen elektronik dengan tujuan agar informasi elektronik dan/atau dokumen elektronik tersebut dianggap seolah-olah data yang otentik."

Bagi si pelaku dikenai sanksi pidana penjara paling lama 12 (dua belas) tahun dan/atau denda paling banyak dua belas miliar rupiah. Hal ini sesuai dengan bunyi Pasal 51 ayat (1) Undang-Undang Nomor 11 Tahun 2008:

"Setiap orang yang memenuhi unsur sebagaimana dimaksud dalam Pasal 35 dipidana dengan pidana penjara paling lama 12 (dua belas) tahun dan/atau denda paling banyak Rp. 12.000.000.000,00 (dua belas miliar rupiah)."

Selain itu dalam UU No. 11 Tahun 2008 juga diatur mengenai larangan bagi setiap orang yang dengan sengaka dan tanpa hak atau melawan hukum mengadakan atau menyediakan perangkat keras atau perangkat lunak komputer yang digunakan untuk memfasiliasi perbuatan penyebarluasan pornografi, karena hal ini merupakan perbuatan yang dilarang dalam Pasal 34 ayat (1) Undang-Undang Nomor 11 Tahun 2008. Sanksi dari orang yang melanggar Pasal 34 ayat (1) UU No. 11 Tahun 2008 ini terdapat dalam bunyi Pasal 50 UU No. 11 Tahun 2008:

"Setiap orang yang memenuhi unsur sebagaimana dimaksud dalam Pasal 34 ayat (1) dipidana dengan pidana penjara paling lama 10 (sepuluh) tahun dan/atau denda paling banyak Rp. 10.000.000.000,00 (sepuluh miliar rupiah)."

Perbuatan itu termasuk keterlibatan seseorang dalam menyediakan fasilitas berupa perangkat keras komputer untuk menggandakan atau memperbanyak file-file pornografi dalam CD atau media penyimpanan yang lain agar dapat disebarluaskan.

b. Pengaturan Undang-Undang Nomor 44 Tahun 2008 tentang Pornografi Pro dan kontra mewarnai sebelum dan sesudah lahirnya Undang-Undang Nomor 44 Tahun 2008 tentang Pornografi terhadap beberapa hal seperti batasan pornografi, sanksi pidana dan peran serta masyarakat. Meskipun demikian, Pemerintah dan DPR RI menyadari sepenuhnya bahwa Indonesia perlu segera memiliki Undang-Undang pornografi dengan pertimbangan bahwa pembuatan, penyebarluasan dan penggunaan pornografi dipandang semakin luas dan dapat mengancam kehidupan 
sosial masyarakat. Dalam perjalanannya, Rancangan Undang-Undang Aksi Pornografi dan Pornoaksi (RUU APP) berganti menjadi RUU Pornografi.

Dengan berlakunya Undang-Undang Nomor 44 Tahun 2008, maka Undang-Undang Nomor 11 Tahun 2008 tentang ITE dan peraturan perundang-undangan yang memuat larangan pornografi tetap berlaku sepanjang tidak bertentangan dengan UndangUndang Nomor 44 Tahun 2008:

"Pada saat undang-undang ini mulai berlaku, semua peraturan perundangundangan yang mengatur atau berkaitan dengan tindak pidana pornografi dinyatakan tetap berlaku sepanjang tidak bertentangan dengan undang-undang ini."

Undang-Undang Nomor 44 Tahun 2008 menjerat setiap orang yang memiliki atau menyimpan produk pornografi. Ketentuan tentang larangan kepelimikian produk pornografi dinyatakan dalam Pasal 6 UU No. 44 Tahun 2008 bahwa:

"Setiap orang dilarang memperdengarkan, mempertontonkan, memanfaatkan, memiliki atau menyimpan produk pornografi kecuali diberi kewenangan oleh perundang-undangan."

Pengertian yang dimaksud "diberi kewenangan oleh perundang-undangan" disini misalnya lembaga sensor film, lembaga pengawasan penyiaran, lembaga penegak hukum, lembaga pelayanan kesehaan dan lembaga pendidikan.

Selanjutnya, Pasal 43 Undang-Undang Nomor 44 Tahun 2008 memerintahkan kepada setiap orang yang menyimpan atau memiliki produk pornografi untuk memusnahkan sendiri atau menyerahkan kepada pihak yang berwajib untuk dimusnahkan dalam waktu paling lama 1 bulan sejak UU Nomor 44 Tahun 2008 berlaku. Pemusnahan yang dimaksud seperti menghapus semua file komputer bermuatan pornografi yang tersimpan di CD, Harddisk, Flash disk atau media penyimpanan lainnya. Tentu bagi orang yang masih menyimpan produk pornografi akan terkena sanksi penjara paling lama 4 (empat) tahun atau denda paling banyak 2 miliar rupiah.

Bagi orang yang memiliki website yang menyajikan cerita porno, foto bugil, film porno dan berbagai informasi bermuatan pornografi akan dijerat dengan Pasal 4 ayat 1 UU Nomor 44 Tahun 2008 dengan pidana penjara paling singkat 6 (enam) bulan dan paling lama 12 (dua belas) tahun dan/atau pidana denda paling sedikit Rp. 250.000.000,00 (dua ratus lima puluh juta) dan paling banyak Rp. 6.000.000.000,00 (enam miliar rupiah). 
Kegiatan seperti meng - copy file pornografi ke CD atau media penyimpanan yan lain, lalu menyewakan atau menjualnya juga termasuk perbuatan yang melanggar Pasal 4 ayat 1 UU No. 44 Tahun 2008, bagi si pelaku dikenakan pidana penjara paling singkat enam bulan dan paling lama dua belas tahun dan/atau pidana denda paling sedikit Rp. 250.000.000,00 (dua ratus lima puluh ribu rupiah) dan paling banyak Rp. 6.000.000.000,00 (enam miliar rupiah).

Hal ini sesuai dengan bunyi Pasal 29 Undang-Undang Nomor 44 Tahun 2008 “Setiap orang yang memproduksi, membuat, memperbanyak, menggandakan, menyebarluaskan, menyiarkan, mengimpor, mengekspor, menawarkan, memperjualbelikan, menyewakan, atau menyediakan pornografi sebagaimana dimaksud dalam Pasal 4 ayat (1) dipidana dengan pidana penjara paling singka enam bulan dan paling lama dua belas tahun dan/atau denda paling sedikit Rp. 250.000.000,00 (dua ratus lima puluh juta) dan paling banyak Rp. 6.000.000.000,00 (enam miliar rupiah)."

Kegiatan seseorang untuk memfasilitasi pembuatan, penggandaan, penyebarluasan, penjualan, penyewaan, penggunaan produk pornografi merupakan kegiatan yang dilarang dalam Pasal 7 Undang-Undang Nomor 44 Tahun 2008. Bagi pelaku yang melanggar Pasal 7 dikenai pidana penjara paling singkat dua tahun dan paling lama lima belas tahun dan/atau denda paling sedikit Rp. 1.000.000.000,00c(satu miliar rupiah) dan paling banyak Rp. 7.500.000.000,00 (tujuh miliar lima ratus juta rupiah). Hal ini sesuai dengan bunyi Pasal 7 UU No. 44 Tahun 2008 "setiap orang yang mendanai atau memfasilitasi perbuatan sebagaimana dimaksud dalam Pasal 7 dipidana dengan pidana penjara paling singkat 2 (dua) tahun dan paling lama 15 (lima belas) tahun dan/atau pidana denda paling sedikit Rp. 1.000.000.000,00 (satu miliar rupiah) dan paling banyak Rp. 7.500.000.000,00 (tujuh miliar lima ratus juta rupiah)."

Setiap orang yang memiliki produk pornografi mendapatkan dengan cara membeli, memperoleh gratis, atau mengunduh dari internet. Mengunduh adalah kegiatan mengalihkan atau mengambil file dari sistem teknologi informasi dan komunikasi. Kegiatan mengunduh sering dilakukan di internet. Tetapi, mengunduh pornografi merupakan perbuatan yang dilarang pada Pasal 5 UU No, 44 Tahun 2008 “setiap orang yang mengunduh pornografi dikenai pidana penjara paling lama 4 (empat) tahun atau denda paling banyak 2 (dua) miliar rupaih." Hal ini sesuai dengan bunyi Pasal 31 Undang-Undang Nomor 44 Tahun 2008. 
Pemerintah telah berupaya untuk melakukan pemblokiran terhadap akses situs porno agar tidak dapat diunduh dengan menyediakan software antipornografi. Meskipun demikian situs porno bertambah jumlahnya setiap saaat sehingga penggunaan software antipornografi perlu dibarengi dengan upaya lain.

Undang-Undang Nomor 44 Tahun 2008 tidak hanya memuat pasal-pasal larangan tetapi memuat pula peran serta masyarakat dan pemerintah untuk mencegah penyebarluasan pornografi. Dalam Pasal 15 dikatakan "Setiap orang berkewajiban melindungi anak dari pengaruh pornografi dan mencegah akses anak terhadap pornografi. " Selanjutnya, dalam ketentuan umum pada Pasal 1 ayat 4 UU Nomor 44 Tahun 2008 yang dimaksud dengan anak adalah seseorang yang belum berusia 18 (delapan belas) tahun. Untuk usia di bahwa 18 tahun, akses oleh anak-anak kemungkinan dilakukan lewat internet, dan tempat yang mudah dijangkau adalah warnet. Bagi pemilik dan pengelola warnet berkewajiban mengawasi dan mencegah akses pornografi lewat internet.

Selain dengan menggunakan upaya penal seperti yang telah dikemukakan di atas, diperlukan juga upaya non-penal dalam menanggulangi kejahatan kesusilan yang bersaranakan internet ini. Upaya non-penal ini perlu dilakukan untuk mendukung dan membantu upaya penal dalam menanggulangi kejahatan, karena upaya penal saja ternyata memiliki banyak kelemahan menyangkut cybersex.

\section{Kebijakan Integral dan Strategis Dalam Penanggulangan Kejahatan}

Meskipun hukum pidana digunakan sebagai ultimatum remidium atau alat terakhir apabila bidang hukum lain tidak dapat mengatasinya, tetapi harus disadari bahwa hukum pidana memiliki keterbatasan kemampuan dalam menanggulangi kejahatan. Terlebih lagi dalam menghadapi cyber crime yang perkembangannya sebagai hitech-crime sangat cepat dan canggih.

Dilihat dari sudut kebijakan kriminal, upaya penanggulangan kejahatan tidak dapat dilakukan secara parsial dengan hukum pidana, tetapi harus ditempuh pula dengan pendekatan integral/sistemik. Sebagai salah satu bentuk dari hitech crime, adalah wajar apabila penanggulangannya juga harus ditempuh dengan cara pendekatan teknologi, pendekatan budaya/kultural, pendekatan regulasi administatif.

Keterbatasan kemampuan dari sarana penal dalam menanggulangi kejahatan dalam dunia maya khususnya cyber sex tersebut juga menjadi pemicu bahwa jalur non-penal 
menjadi alternatif yang efektif dalam penanggulangan kejahatan di samping upaya penal. Jalur non-penal lebih menitikberatkan pada sifat pre-emtif dan preventif sebelum kejahatan terjadi, sehingga sasaran utamanya adalah menghalangi faktor-faktor kondusif penyebab terjadinya kejahatan. Upaya non-penal dalam penanggulangan tindak kejahatan kesusilaan yang bersaranakan internet (cybersex) dapat meliputi:

a. Pengawasan terhadap situs-situs yang ada di Internet oleh Kementerian Informasi dan Telekomunikasi;

b. Pengenalan dan pemahaman agama yang baik yang dimulai sejak usia dini;

c. Peningkatan kesadaran/pemahaman mengenai Internet kepada masyarakat, bahwa tujuan penggunaan Internet adalah untuk kemajuan masyarakat.

d. Pendampingan orang tua pada saat anak sedang menggunakan internet

Tentunya keterbukaan komunikasi antara orang tua dan anak, sehingga anak tidak lagi hanya menerima larangan namun juga menerima pemahaman apabila mereka dilarang untuk melakukan sesuatu.

\section{PENUTUP}

\section{A. Simpulan}

Cyber sex adalah merupakan bentuk baru perzinahan sehingga diperlukan pengaturan hukum yang jelas untuk dapat mengantisipasinya. Selain upaya penal tersebut upaya non penal harus dikedepankan untuk menanggulangi cybersex. Terhadap cybersex dapat dilakukan penegakan hukum dengan hukum positif yang ada pada saat ini dengan melakukan konstruksi hukum. Selain itu juga pengaturan oleh hukum positif Indonesia masih tersebar dalam berbagai peraturan perundang-undangan dan masih terdapat beberapa kekurangan, sehingga kedepannya diperlukan kebijakan antisipatif hukum pidana yang akan datang.

Meskipun hukum pidana digunakan sebagai ultimatum remidium atau alat terakhir apabila bidang hukum lain tidak dapat mengatasinya, tetapi harus disadari bahwa hukum pidana memiliki keterbatasan kemampuan dalam menanggulangi kejahatan.

Keterbatasan tersebut juga menjadi pemicu bahwa jalur non-penal menjadi alternatif yang efektif dalam penanggulangan kejahatan di samping upaya penal. Jalur non-penal lebih menitikberatkan pada sifat pre-emtif dan preventif sebelum kejahatan terjadi, sehingga sasaran utamanya adalah menghalangi faktor-faktor kondusif penyebab terjadinya kejahatan. Upaya non-penal dalam penanggulangan tindak kejahatan kesusilaan yang 
bersaranakan internet (cybersex) dapat ditempuh dengan cara pendekatan teknologi, pendekatan budaya, dan pendekatan regulasi administrasi.

\section{B. Saran}

Pemerintah dan Pemerintah Daerah wajib melakukan pencegahan pembuatan, penyebarluasan dan penggunaan pornografi (cybersex) dengan cara melakukan pemutusan jaringan pembuatan dan penyebarluasan produk atau jasa pornografi (cybersex), termasuk pemblokiran melalui internet.

Pemerintah daerah berwenang mengembangkan edukasi melalui penyuluhan ke sekolah-sekolah tentang bahaya dan dampak pornografi (cybersex). Disamping itu, Masyarakat diharapkan dapat ikut berperan serta untuk mencegah penyebarluasan pornografi dan cybersex dengan melaporkan pelanggaran, melakukan sosialisasi kepada masyarakat tentang pornografi. Peran serta masyarakat harus sesuai dengan peraturan perundang-undangan yang berlaku, yang mana hal ini ditegaskan dalam bagian penjelasan Undang-Undang Nomor 44 Tahun 2008.

\section{DAFTAR REFERENSI}

Abdul Wahid. Kejahatan Mayantara. Bandung: Refika Aditama. 2005

Agus Rahardjo. Cyber Crime: Pemahaman dan Upaya Pencegahan Kejahatan

Berteknologi. Bandung: PT Citra Aditya Bakti. 2002

Barda Nawawi Arief. Antisipasi Hukum Pidana dan Perlindungan Korban Cybercrime di Bidang Kesusilaan. Makalah pada Seminar Kejahatan Seks Melalui Cyber Crime dalam Perspektif Agama, Hukum dan Perlindungan Korban. Fakultas Hukum UNSWAGATI 20 Agustus 2005

- Bunga Rampai Kebijakan Hukum Pidana (Perkembangan Penyusunan Konsep KUHP Baru). Jakarta: Kencana Prenada Media Group. 2008 Masalah Penegakan Hukum dan Kebijakan Hukum Pidana dalam Penanggulangan Kejahatan. Jakarta: Kencana Prenada Media Group. 2008 Kebijakan Legislatif Dalam Penanggulangan Kejahatan Dengan Pidana Penjara. Semarang: Ananta. 1994

Data Protection Working Party, Council of Europe. "Opinion 4/2001 On the Council of Europe's Draft Convention on Cyber Crime." Adopted on 22 March 2001. 500/01/EN/Final WP 41

John M Echols dan Hasan Shadily. Kamus Inggris - Indonesia. 2000

Lilik Mulyadi. Bunga Rampai Hukum Pidana, Teoretis dan Praktek. Bandung: PT Alumni. 2008 
Leden Marpaung. Kejahatan Terhadap Kesusilaan dan Masalah Prevensinya. Jakarta: Sinar Grafika. 1996

Mahmud Mulyadi. Criminal Policy: Pendekatan Integral Penal Policy dan Non

Penal Policy dalam Penanggulangan Kejahatan Kekerasan. Medan: Pustaka Bangsa Pers. 2008

Mark Griffiths. Sex on the Internet: Observations and Implications for Internet Sex Addiction on Journal Of Sex Research. November 2001

M. Hamdan. Politik Hukum Pidana. Jakarta: Raja Grafindo. 1997

Mulyana W. Kusuma. Perumusan Tindak Pidana Kesusilaan (Perzinahan dan Pemerkosaan) dalam Rancangan KUHP Baru ditinjau dari Aspek Kebijakan Kriminal dan Aspek Sosial dan Budaya. Makalah disajikan dalam Seminar Sehari tentang Tinjauan Rancangan KUHP Baru Khususnya Tindak Pidana Kesusilaan. Fakultas Hukum Universitas Katolik Soegihapranata. Semarang 20 Febuari 1993

Peter G. Hoefnagels. The Other Side Of Criminology. Deventer: Kluwer-Holland. 1973

Roeslan Saleh. Bab-Bab Kodifikasi Hukum Pidana (buku II). Dalam Lokakarya diselenggarakan oleh BPHN Departemen Kehakiman. Jakarta 23 - 25 April 1985

Soerjono Soekanto dan Sri Mamudji. Penelitian Hukum Normatif. Jakarta: Rajawali Pers. 2010

Sudarto. Kapita Selekta Hukum Pidana. Bandung: Alumni. 1986 Hukum dan Hukum Pidana. Bandung: Alumni. 1983

Art Bowker and Michael Gray. An Introduction to The Supervision of The Cybersex Offender. http://uscourt.gov

Gloria G. Brame. How to have Cyber Sex: Boot Up and Turn On http://www.gloriabrame.com/glory/journ.html

Kenneth Allen. Cyber-sex A Review and Implications of The Situation. http://home.earthlink.net

Marlene M. Maheu. The Future of Cyber Sex and Relationship Fidelity. http://www.selfhelpmagazine.com

Michael G. Conner. Internet Addiction and Cyber Sex. http://www.CrisisCounseling.org

Nathan Tabor. Adultary is Killing The American Family http://theconervativevoice.com/

Peter David Goldberg. An Explonatory Study About the Impacts that cybersex (The Use of the Internet for Sexual Purposes) is having on Families and The Practices of Marriage and Family Therapist. 2004 http://pedrogoldberg@aol.com

NN. The Cyber AA Discussion Board. http://www.salagram.net/cyber.html 